\title{
APELA wt Allele
}

National Cancer Institute

\section{Source}

National Cancer Institute. APELA wt Allele. NCI Thesaurus. Code C137985.

Human APELA wild-type allele is located in the vicinity of $4 q 32.3$ and is approximately 22 $\mathrm{kb}$ in length. This allele, which encodes apelin receptor early endogenous lig and protein, is involved in apelin receptor binding and in the development of the heart and cardiovascular system. 